\title{
METODE FORWARD-BACKWARD CAPON UNTUK ESTIMASI PARAMETER PADA APLIKASI RADAR MULTI-ANTENA
}

\author{
Petrick $^{1}$, Syahfrizal Tahcfulloh ${ }^{2}$ \\ ${ }^{1,2}$ Jurusan Teknik Elektro, Universitas Borneo Tarakan, Tarakan, Kalimantan Utara, Indonesia \\ ${ }^{1}$ petrickpada220@gmail.com \\ ${ }^{2}$ rizalubtegmail. com
}

\begin{abstract}
Multi-antenna radar systems are generally the Phased Array (PA) and the Multiple-Input Multiple-Output (MIMO) radars, each of which has the main advantages of high coherent gain and high waveform diversity gain. There are many parameters that determine the performance of these radars, one of which is the estimation parameter which is proportional to the radar's ability to determine the number of detectable targets. In this paper, a parameter estimation using the Forward-Backward Capon (FBCapon) method is proposed which has the main advantage of being able to detect the direction of arrival (DoA) with high resolution compared to other conventional methods. The formulation and evaluation of its performance is carried out on factors such as: variation of radar cross section (RCS) of the target, number of DoA, angular resolution between two targets, amplitude detection accuracy, and number of antenna elements on the transmitterreceiver $(T x-R x)$. The effectiveness of the estimator performance is compared with the LS estimation applied to both types of radar where the DoA detection capability of the two variants of the Capon method is more accurate than the LS method. The FBCapon estimator has an RMSE of amplitude estimate that is half lower than that obtained by the FCapon estimator. The resolution of the detection angle is better than the $L S$ estimator, for example for $K=L=8$ then the angle resolution is $5^{\circ}$ while the LS estimator is $5.8^{\circ}$.
\end{abstract}

Keywords-Capon estimator, MIMO radar, parameter estimation, phased-array radar.

Intisari-Sistem radar multi-antena umumnya berupa radar Phased Array (PA) dan Multiple-input MultipleOutput (MIMO) yang masing-masing memiliki kelebihan utama berturut-turut yaitu gain koheren yang tinggi dan gain peragaman sinyal (waveform) yang tinggi. Banyak parameter penentu kinerja radar-radar ini salah satunya yaitu estimasi parameter yang proporsional dengan kemampuan radar dalam menentukan jumlah target. Pada penelitian ini diusulkan suatu estimasi parameter dengan metode Forward-Backward Capon (FBCapon) yang memiliki kelebihan utama yaitu mampu mendeteksi sudut kedatangan sinyal echo atau direction of arrival (DoA) beresolusi tinggi dibanding metode konvensional yang lain. Formulasi dan evaluasi kinerjanya dilakukan terhadap faktor-faktor seperti: variasi radar cross section (RCS) dari target, jumlah DoA, resolusi sudut antar dua target, akurasi deteksi amplitudo, dan jumlah elemen antena pada transmitter-receiver (Tx-Rx). Keefektifan dari kinerja metode ini dibandingkan dengan estimasi LS yang diterapkan pada kedua jenis radar dimana kemampuan deteksi DoA kedua metode Capon lebih akurat dibanding metode LS. Estimator FBCapon memiliki RMSE pada estimasi amplitudo separuh lebih rendah dari yang diperoleh FCapon. Resolusi sudut deteksinya lebih baik dari estimator LS, sebagai contoh untuk $K=L=8$ maka diperoleh resolusi sudut $5^{\circ}$ sedangkan estimator LS sebesar $5, \mathbf{8}^{\mathbf{0}}$.

Kata Kunci-Estimasi parameter, estimator Capon, radar phased array, radar MIMO.

\section{PENDAhUluAN}

Teknologi pada saat ini berkembang begitu pesat, salah satunya di bidang teknologi radar. Radar (RAdio Detection And Ranging) adalah suatu sistem yang bekerja dengan memancarkan gelombang elektromagnetik untuk mendeteksi posisi (jarak/range) dan kecepatan (velocity) dari suatu objek. Penggunaan radar sering dimanfaatkan di bidang militer, pelayaran, penerbangan, informasi cuaca, dan lain-lain. Sistem radar terdiri dari transmitter (Tx) dan receiver $(\mathrm{Rx})$. Transmitter berfungsi untuk memancarkan gelombang elektromagnetik ke suatu objek, sedangkan receiver berfungsi sebagai penerima kembali pantulan gelombang elektromagnetik (echo) dari sinyal yang terdeteksi oleh target radar.

Pada beberapa dekade terakhir, muncul pengembangan di bidang radar multi-antena atau banyak elemen antena, yang salah satunya dinamakan radar Phased-Array (PA). Radar PA memanfaatkan pergeseran fase pada setiap elemen antenanya untuk mengatur beam menuju ke arah target yang diinginkan. Hal ini disebabkan adanya penguatan koheren yang tinggi maka radar ini dapat mendeteksi suatu target yang jauh dan kecil [1].

Sementara itu ada juga jenis radar multi-antena lain seperti radar Multiple Input Multiple Output (MIMO). Radar MIMO menggunakan beberapa antena untuk memancarkan sinyal orthogonal yang mampu memaksimalkan jumlah target yang dapat dideteksi [2] [3]. Hal ini dapat terjadi karena tiap-tiap sinyal (waveform) yang dipancarkan oleh $\mathrm{Tx}$ dengan mudah dibedakan satu dengan lainnya karena adanya sifat orthogonal tersebut. Melalui beberapa elemen antena yang ada pada radar MIMO dapat ditransmisikan banyak waveform orthogonal sehingga radar ini bersifat waveform diversity yaitu memiliki banyak peragaman sinyal radar sehingga meningkatkan jumlah objek yang dideteksi.

Berbagai kinerja radar telah diuraikan oleh para peneliti di bidang radar multi-antena terutama yang berkaitan dengan identifikasi atau estimasi parameter target. Metode estimasi parameter dengan Least Square (LS) memiliki kelemahan rendah resolusi dan memiliki 
sidelobes yang tinggi [4] - [5]. Disamping itu juga teknik ini memiliki deteksi amplitudo yang tidak akurat dimana amplitudo terukur proporsional dengan RCS, serta memiliki resolusi sudut yang kurang baik [6]. Hasil estimasi parameter yang berbeda jika menggunakan estimator Capon, dimana estimator ini memiliki kelebihan dapat mendeteksi lokasi target dan dapat memperkirakan amplitudo yang kompleks serta memiliki resolusi sudut yang lebih baik [7].

Metode estimasi parameter dengan Capon pada radar MIMO telah dilakukan oleh peneliti namun kinerjanya dikaji berdasarkan pengaruh ukuran RCS dan DoA [7]. Di samping itu juga estimator Capon yang dimanfaatkan sejauh ini pada radar ini bersifat forward Capon (FCapon) [4]. Sehingga kontribusi utama pada penelitian ini adalah memformulasikan jenis estimator Capon yang dinamakan forward-backward Capon (FBCapon). Kinerja estimator ini diinvestigasi berdasarkan pengaruh banyaknya DoA target, jumlah antena pada Tx-Rx, besar resolusi sudut deteksi antar dua target, akurasi amplitudo yang terdeteksi, dan variasi ukuran RCS.

Pada makalah ini dilakukan formulasi dan evaluasi kinerja estimator yang diusulkan terhadap radar PA dan MIMO yang selanjutnya dibandingkan kinerjanya terhadap estimator LS dan FCapon menurut semua parameter-parameter yang telah disebutkan sebelumnya. Kemudian dilakukan analisis terhadap kemampuan semua estimator tersebut untuk dua jenis radar yaitu radar PA dan MIMO.

Makalah ini diorganisasi sebagai berikut. Bagian II mengulas tentang radar multi-antena yaitu radar PA dan MIMO. Pada Bagian III menyajikan uraian tentang estimator FCapon dan FBCapon terkait formulasinya. Beberapa contoh-contoh simulasi numerik, evaluasi, dan analisanya diberikan pada Bagian IV. Akhirnya makalah ini disimpulkan pada Bagian V.

\section{RADAR MULTI-ANTENA}

Seperti yang sudah diketahui, radar PA memberikan directional gain yang berguna untuk mendeteksi target yang lemah dan menekan level sidelobe ke arah datang interferensi. Misalkan suatu sistem radar dengan antenaantena yang co-located memiliki $K$ antena pada array Tx dan $L$ antena pada array $\mathrm{Rx}$. Sinyal pada $\mathrm{Rx}$ akan melewati matched filter (MF) untuk dipisahkan terhadap sinyal transmit menjadi vektor data $L \times 1$ yaitu [8]

$$
\mathbf{y}_{\mathrm{PA}}=\sum_{p} \sigma_{p}\left(\theta_{p}\right) \mathbf{u}_{\mathrm{PA}}\left(\theta_{p}\right)+\mathbf{n}_{\mathrm{PA}}
$$

dengan vektor steering Tx-Rx yaitu

$$
\mathbf{u}_{\mathrm{PA}}(\theta)=\beta \mathbf{b}(\theta)
$$

dengan $\sigma_{l}$ dan $\sigma_{i}$ berturut-turut menyatakan amplitudo kompleks sinyal ditransmit dari target dan interferensi, $\beta$ merupakan gain direksional beampattern pada $\mathrm{Tx}, \mathbf{b}(\theta)$ adalah vektor perambatan $L \times 1$ yang terjadi karena delay perambatan dari Tx ke $\mathrm{Rx}$, dan $\mathbf{n}_{\mathrm{PA}}$ adalah $L \times 1$ vektor additive white Gaussian noise dengan rerata nol dan matriks kovarians $\sigma_{\mathrm{n}}^{2} \mathbf{I}_{L L}$. Untuk kondisi array $\mathrm{Tx}$ dan array $\mathrm{Rx}$ yang co-located maka vektor steering $\mathrm{Rx} \mathbf{b}(\theta)$ definisinya sama dengan vektor steering $\mathrm{Tx} \mathbf{a}(\theta)$.

Pada radar MIMO telah diakui dapat memperbaiki resolusi radar [9]. Idenya adalah dengan $K$ antena pada Tx dipancarkan $K$ waveform yang orthogonal satu dengan lain yang kemudian diterima oleh $L$ antena di Rx. Adanya MF di Rx akan memisahkan $K$ waveform tersebut dengan tepat. Telah dibuktikan bahwa beampattern total pada radar ini merupakan hasil perkalian beampattern pada Tx dan Rx sehingga memberikan resolusi yang tinggi [10]. Radar ini menunjukkan juga bahwa waveform yang dipantulkan berasal dari banyak target bersifat independen secara linier sehingga mendukung penerapan banyak teknik estimasi adaptif guna memperoleh resolusi yang tinggi sekaligus mampu menolak interferensi atau jamming.

Radar MIMO mempunyai transmisi omnidireksional pada semua elemen transmitnya tanpa membentuk suatu beam direksional [8]. Sinyal Rx kemudian dilewatkan pada MF, maka akan menghasilkan vektor data $K L \times 1$ yaitu

$$
\mathbf{y}_{\mathrm{MIMO}}=\sum_{p} \sigma_{p}\left(\theta_{p}\right) \mathbf{u}_{\mathrm{MIMO}}\left(\theta_{p}\right)+\mathbf{n}_{\mathrm{MIMO}}
$$

dengan vektor steering Tx-Rx yaitu

$$
\mathbf{u}_{\text {MIMO }}(\theta)=\mathbf{a}(\theta) \otimes \mathbf{b}(\theta)
$$

dengan $\otimes$ menyatakan perkalian Kronecker.

Berdasarkan (2) dan (4), tidak seperti radar PA yang memberikan directional gain pada arah target $\theta$ maka radar MIMO dapat meningkatkan degree of freedom (DoF), resolusi spasial meningkat, dan kinerja deteksi meningkat juga [8].

\section{METODE PENELITIAN}

A. Metode Forward Capon sebagai Estimasi Parameter Pada estimasi target $\hat{\sigma}(\theta)$ dengan metode LS ternyata mengalami kelemahan berupa high sidelobes dan low resolution [2], [3], [5]. Di kondisi dengan strong interference dan jamming maka metode LS tidak berfungsi dengan baik. Untuk memperoleh estimasi target dengan resolusi tinggi dan kemampuan menekan interferensi cukup baik maka dapat digunakan metode Capon beamforming atau Minimum Variance Distortionless Response (MVDR) [11] - [12]. Bila dinyatakan kembali sinyal ekuivalen baseband yang diterima oleh $L$ elemen antena pada array $\mathrm{Rx}$ dengan arah target $\theta_{p}$ dinyatakan dengan vektor

$$
\mathbf{y}_{\text {MIMO }}(t)=\sum_{p=1}^{P} \sigma_{p}\left(\theta_{p}\right) \mathbf{b}\left(\theta_{p}\right) \mathbf{a}^{T}\left(\theta_{p}\right) \boldsymbol{\psi}(t)+\mathbf{n}(t)
$$

dengan $(\cdot)^{T}$ adalah operator transpose, $\mathbf{a}(\theta)=[1$ $\left.e^{-j 2 \pi d_{K} \sin (\theta) / \lambda} \ldots . \quad e^{-j 2 \pi(K-1) d_{K} \sin (\theta) / \lambda}\right]^{T}$ yaitu vektor steering $K \times$ 1 pada $\operatorname{Tx}, \mathbf{b}(\theta)=\left[\begin{array}{llll}1 & e^{-j 2 \pi d_{L} \sin (\theta) / \lambda} & \ldots & e^{-j 2 \pi(L-1) d_{L} \sin (\theta) / \lambda}\end{array}\right]^{T}$ yaitu vektor steering $L \times 1$ pada $\mathrm{Rx}, \psi(t)=\left[\varphi_{1}(t) \varphi_{2}(t) \ldots \varphi_{K}(t)\right]^{T}$ yaitu vektor waveform $K \times 1$ dari Tx dengan $\varphi_{k}(t)$ adalah sinyal baseband transmisi waktu diskrit $t=1, \ldots, Q$, $\sigma_{p}\left(\theta_{p}\right)$ adalah koefisien refleksi radar dari target yang proporsional dengan RCS, $p$ adalah jumlah target yang 
memantulkan sinyal pantul ke $\operatorname{Rx} p=1,2, \ldots, P, \theta_{p}$ adalah lokasi target, dan $\mathbf{n}(t)$ adalah vektor $L \times 1$ dari interference plus noise. Parameter yang akan diestimasi dari $\mathbf{y}_{\text {MIMO }}(t)$ adalah $\left\{\sigma_{p}\left(\theta_{p}\right)\right\}_{p=1}^{P}$ dan $\left\{\theta_{p}\right\}_{p=1}^{P}$. Jika diasumsikan $\mathbf{n}(t)$ tidak berkorelasi dengan $\psi(t)$ maka sifat identifiabilitas pada suku pertama dari (5) tidak dipengaruhi oleh suku kedua.

Berikut ini metode Capon yang digunakan untuk mengestimasi jumlah target pada radar MIMO dari (5) dapat dilakukan dengan tahapan yaitu: (a) penentuan beamforming Capon dan (b) estimasi target $\hat{\sigma}(\theta)$ seperti metode LS. Selanjutnya metode ini dikenal dengan nama forward-Capon (FCapon) [13].

Beamformer dari FCapon diformulasikan berikut

$$
\min _{\mathbf{w}} \mathbf{w}^{H} \hat{\mathbf{R}}_{\mathbf{y y}} \mathbf{w} \text { terhadap } \mathbf{w}^{H} \mathbf{b}(\theta)=1
$$

dimana $(\cdot)^{H}$ adalah operator Hermitian transpose, $\mathbf{w} \in$ $C^{L \times 1}$ adalah vektor bobot untuk meningkatkan noise, interference, dan jamming suppression sedangkan sinyal yang diinginkan tidak terdistorsi, $\hat{\mathbf{R}}_{\mathbf{y y}}$ adalah matriks kovarians dari sinyal data yang diterima yaitu

$$
\hat{\mathbf{R}}_{\mathbf{y y}}=(1 / Q) \sum_{q=1}^{Q} \mathbf{y}(q) \mathbf{y}^{H}(q)
$$

dimana $Q$ adalah jumlah sampel data.

Berdasarkan pada [11] dan [12] maka vektor bobot untuk beamformer dari FCapon dinyatakan oleh

$$
\hat{\mathbf{w}}_{\mathrm{FC}}=\frac{\hat{\mathbf{R}}_{\mathbf{y y}}^{-1} \mathbf{b}(\theta)}{\mathbf{b}^{H}(\theta) \hat{\mathbf{R}}_{\mathbf{y y}}^{-1} \mathbf{b}(\theta)}
$$

sehingga output beamformer dari FCapon untuk vektor sinyal data yang diterima adalah

$$
\hat{\mathbf{w}}_{\mathrm{FC},}^{H} \mathbf{y}_{\mathrm{MIMO}}(t)=\frac{\mathbf{b}^{H}(\theta) \hat{\mathbf{R}}_{\mathrm{yy}}^{-1} \mathbf{y}(t)}{\mathbf{b}^{H}(\theta) \hat{\mathbf{R}}_{\mathbf{y y}}^{-1} \mathbf{b}(\theta)}
$$

dengan $\mathbf{y}_{\text {MIMO }}(t)$ pada (1) kemudian diterapkan metode LS terhadap (9) maka diperoleh estimasi target untuk FCapon pada radar MIMO seperti berikut.

$$
\hat{\sigma}_{\mathrm{FC}}(\theta)=\frac{\sum_{q=1}^{Q} \mathbf{b}^{H}(\theta) \hat{\mathbf{R}}_{\mathbf{y y}}^{-1} \hat{\mathbf{R}}_{\mathbf{y} \psi} \mathbf{a}^{*}(\theta)}{\left[\mathbf{b}^{H}(\theta) \hat{\mathbf{R}}_{\mathbf{y y}}^{-1} \mathbf{b}(\theta)\right]\left[\mathbf{a}^{T}(\theta) \hat{\mathbf{R}}_{\psi \psi} \mathbf{a}^{*}(\theta)\right]}
$$

dengan

$$
\begin{aligned}
& \hat{\mathbf{R}}_{\mathbf{y} \boldsymbol{\psi}}=(1 / Q) \sum_{q=1}^{Q} \mathbf{y}(q) \boldsymbol{\psi}^{H}(q) \\
& \hat{\mathbf{R}}_{\psi \boldsymbol{\psi}}=(1 / Q) \sum_{q=1}^{Q} \boldsymbol{\psi}(q) \boldsymbol{\psi}^{H}(q)
\end{aligned}
$$

B. Metode Forward-Backward Capon sebagai Estimasi Parameter

Berikut disajikan ulasan terkait penurunan estimasi forward-backward Capon (FBCapon) untuk radar MIMO yang merupakan perluasan analogi dari aplikasi FBAPES untuk aplikasi spektrum sinyal oleh [12] dan merupakan kontribusi utama pada penelitian ini. Metode pererataan forward-backward telah banyak dimanfaatkan untuk meningkatkan kinerja pada aplikasi analisis spektral [12] yaitu untuk untuk metode APES. Sebelumnya telah disajikan estimasi parameter radar MIMO dengan metode FCapon yang menggunakan vektor data dari sinyal yang diterima "maju" (forward) yaitu $\mathbf{y}(q)=\left[\begin{array}{lll}y(q) & y(q+1) & \ldots\end{array}\right.$ $y(q+L-1)]^{T}$. Untuk vektor dari sinyal yang diterima "mundur" (backward) yaitu $\tilde{\mathbf{y}}(q)=\left[y^{*}(Q-q-1) \quad y^{*}(Q\right.$ $\left.-q-2) \quad \ldots \quad y^{*}(Q-q-L)\right]^{T}$. Bila dikehendaki output dari data forward dan backward maka formulasinya FBCapon dinyatakan dengan

$$
\min _{\mathbf{w}}(1 / 2 Q) \sum_{q=1}^{Q}\left\{\mathbf{w}^{H} \hat{\mathbf{R}}_{\mathbf{y y}} \mathbf{w} \|\left[\mathbf{w}^{H} \breve{\mathbf{R}}_{\tilde{\mathbf{y}} \tilde{\mathbf{y}}} \mathbf{w}\right]\right\}
$$

terhadap $\mathbf{w}^{H} \mathbf{b}(\theta)=1$. Serupa dengan cara memperoleh (8) maka diperoleh vektor bobot untuk beamformer dari FBCapon yaitu

$$
\hat{\mathbf{w}}_{\mathrm{FBC}}=\frac{1}{2}\left(\frac{\hat{\mathbf{R}}_{\mathbf{y}}^{-1} \mathbf{b}(\theta)}{\mathbf{b}^{H}(\theta) \hat{\mathbf{R}}_{\mathbf{y y}}^{-1} \mathbf{b}(\theta)}+\frac{\breve{\mathbf{R}}_{\tilde{\mathbf{y}} \mathbf{y}}^{-1} \mathbf{b}(\theta)}{\mathbf{b}^{H}(\theta) \breve{\mathbf{R}}_{\tilde{\mathbf{y}} \tilde{\mathbf{y}}}^{-1} \mathbf{b}(\theta)}\right)
$$

sehingga output beamformer dari FBCapon untuk vektor sinyal data yang diterima adalah

$$
\hat{\mathbf{w}}_{\mathrm{FBC}}^{H} \mathbf{y}(t)=\frac{1}{2}\left(\frac{\mathbf{b}^{H}(\theta) \hat{\mathbf{R}}_{\mathbf{y y}}^{-1} \mathbf{y}(t)}{\mathbf{b}^{H}(\theta) \hat{\mathbf{R}}_{\mathbf{y y}}^{-1} \mathbf{b}(\theta)}+\frac{\mathbf{b}^{H}(\theta) \breve{\mathbf{R}}_{\tilde{\mathbf{y}} \mathbf{y}}^{-1} \mathbf{y}(t)}{\mathbf{b}^{H}(\theta) \breve{\mathbf{R}}_{\tilde{\mathbf{y}} \mathbf{y}}^{-1} \mathbf{b}(\theta)}\right)
$$

kemudian terapkan metode LS pada (15) maka akan diperoleh estimasi target dari FBCapon untuk radar MIMO yaitu

$$
\begin{aligned}
& \hat{\sigma}_{\mathrm{FBC}}(\theta) \\
& =\frac{1}{2}\left(\frac{\sum_{q=1}^{Q} \mathbf{b}^{H}(\theta) \hat{\mathbf{R}}_{\mathbf{y y}}^{-1} \hat{\mathbf{R}}_{\mathbf{y} \psi} \mathbf{a}^{*}(\theta)}{\left[\mathbf{b}^{H}(\theta) \hat{\mathbf{R}}_{\mathbf{y y}}^{-1} \mathbf{b}(\theta)\right]\left[\mathbf{a}^{T}(\theta) \hat{\mathbf{R}}_{\psi \psi} \mathbf{a}^{*}(\theta)\right]}\right. \\
& \left.\quad+\frac{\sum_{q=1}^{Q} \mathbf{b}^{H}(\theta) \breve{\mathbf{R}}_{\tilde{\mathbf{y}} \tilde{\mathbf{y}}}^{-1} \breve{\mathbf{R}}_{\tilde{\mathbf{y}} \psi} \mathbf{a}^{*}(\theta)}{\left[\mathbf{b}^{H}(\theta) \breve{\mathbf{R}}_{\tilde{\mathbf{y}} \tilde{\mathbf{y}}}^{-1} \mathbf{b}(\theta)\right]\left[\mathbf{a}^{T}(\theta) \hat{\mathbf{R}}_{\psi \psi} \mathbf{a}^{*}(\theta)\right]}\right)
\end{aligned}
$$

dengan

$$
\begin{aligned}
\breve{\mathbf{R}}_{\tilde{\mathbf{y}} \boldsymbol{\psi}} & =(1 / Q) \sum_{q=1}^{Q} \tilde{\mathbf{y}}(q) \boldsymbol{\psi}^{H}(q) \\
\breve{\mathbf{R}}_{\tilde{\mathbf{y}} \tilde{\mathbf{y}}} & =(1 / Q) \sum_{q=1}^{Q} \tilde{\mathbf{y}}(q) \tilde{\mathbf{y}}^{H}(q)
\end{aligned}
$$

\section{HASIL DAN PEMBAHASAN}

Evaluasi kinerja estimasi parameter target dengan metode FCapon dan FBCapon pada radar MIMO berturut-turut menggunakan (10) dan (16) sedangkan metode LS menggunakan (44) pada [5]. Kinerja semua estimator pada dua jenis radar disajikan sebagai grafik modulus amplitudo kompleks (MAK) yang bervariasi terhadap DoA dimana MAK proporsional dengan RCS dinyatakan sebagai $\hat{\sigma}(\theta)$. Bila diasumsikan jumlah elemen antena pada array di Tx-Rx adalah sama, yaitu $K$ $=L=8$ elemen. Spasi antar elemen antena pada array $\mathrm{Tx}-$ Rx adalah setengah panjang gelombang.

A. Kinerja Semua Estimator terhadap Jenis Radar

Untuk membandingkan kinerja estimator parameter antara metode yang diusulkan, yaitu FBCapon, dengan 
metode yang lain, yaitu LS dan FCapon, pada kedua jenis radar multi-antena, yaitu PA dan MIMO, maka diasumsikan ada tiga target berlokasi di $\Theta_{\mathrm{A}}=\left\{-25^{\circ} ;-5^{\circ}\right.$; $\left.15^{\circ}\right\}$ dengan amplitudo kompleks yang proporsional dengan RCS untuk semua target yaitu $\sigma\left(\Theta_{\mathrm{A}}\right)=1$. Pada Gambar 1(a) - 1(b) menunjukkan MAK untuk kinerja semua estimator yang diterapkan seperti LS, FCapon, dan FBCapon pada dua jenis radar yaitu PA dan MIMO.

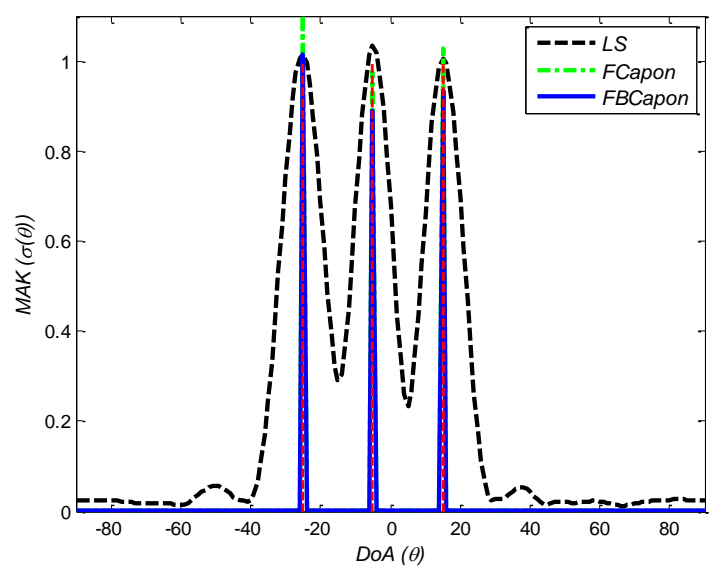

(a)

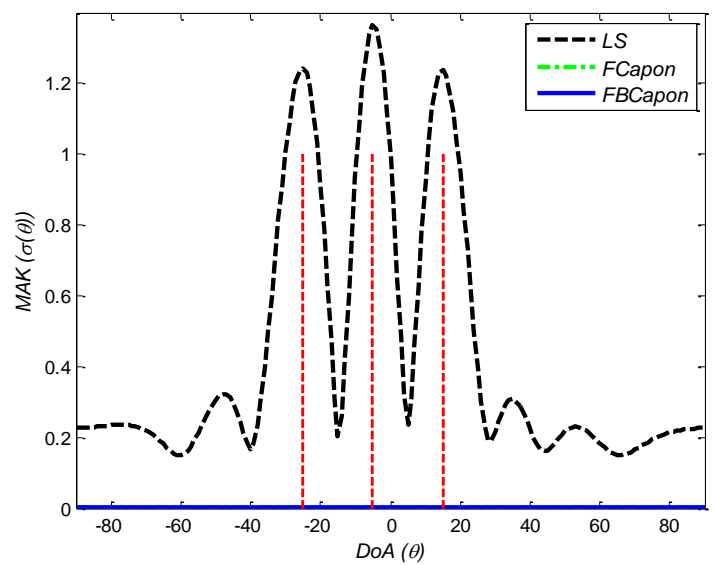

(b)

Gambar 1. Modulus amplitudo kompleks dari berbagai estimator dengan $\Theta_{\mathrm{A}}$ dan RCS sama untuk: (a) radar MIMO dan (b) radar PA.

Untuk radar MIMO, kinerja estimator-estimator tersebut secara umum mampu mendeteksi ketiga target dengan tepat seperti pada Gambar 1(a) baik dalam deteksi MAK yaitu mendekati nilai $\mathrm{RCS}=1$ dan semua DoA pada $\Theta_{\mathrm{A}}$ terdeteksi dengan tepat. Sebaliknya pada radar PA di Gambar 1(b), hanya estimator LS yang berfungsi mendeteksi ketiga target walaupun MAK memiliki resolusi yang tidak tepat. Hal ini diulas lebih lanjut pada Bagian IV. F yang menunjukkan pengaruh jumlah elemen array di Tx-Rx terhadap kinerja estimator. Radar PA termasuk memiliki jumlah waveform yang ditransmit paling sedikit yaitu semua elemen pada array di Tx, yaitu $K=8$, memancarkan satu waveform saja sehingga sulit untuk mendeteksi banyak target apalagi untuk deteksi DoA maupun MAK yang tepat. Hal tersebut sejalan dengan studi yang dilaporkan oleh [7] yaitu kemampuan deteksi semakin meningkat dengan naiknya jumlah subarray dimana untuk radar PA subarray-nya bernilai 1 sedangkan radar MIMO memiliki subarray $K$. Untuk radar MIMO kemampuan deteksi target tinggi karena semua elemen antena pada array di $\mathrm{Tx}$ memancarkan $K$ waveform sehingga berdampak pada tingginya peragaman waveform seperti yang telah dibahas oleh [5].

Tampak juga dari Gambar 1(a), bahwa dengan menggunakan estimator FCapon dan FBCapon memiliki resolusi sudut DoA untuk deteksi lokasi target-target $\Theta_{\mathrm{A}}$ lebih akurat dibanding metode LS. Meskipun dari sisi akurasi MAK pada metode LS relatif lebih baik (lihat Gambar 1(b)). Khusus pada radar MIMO di Gambar 1(a), tidak serupa dengan metode LS, kedua estimator Capon hampir tidak memiliki sidelobe sehingga kondisi ini menguntungkan bila berhadapan dengan strong interference dan jamming. Kondisi dan kemampuan estimator Capon tersebut sejalan dengan hasil yang diperoleh oleh [7] mengenai penekanan terhadap sidelobe.

Kedua estimator Capon unggul dalam hal deteksi DoA dibanding metode LS (lihat Gambar 1(a)). Untuk melihat kelebihan akurasi deteksi DoA pada kedua estimator Capon tersebut maka dibandingkan dari kemampuan estimasi amplitudonya. Hasil deteksi amplitudo MAK untuk $\Theta_{\mathrm{A}}$ pada ketiga estimator untuk radar MIMO tertabulasi pada Tabel I. Metode membandingkan kinerja ketiga estimator tersebut dengan menggunakan pendekatan Root Mean Square Error (RMSE) terhadap modulus dari amplitudo kompleks sasaran yaitu RCS bernilai 1. RMSE bisa dinyatakan dengan

$$
R M S E=\sqrt{\frac{\left(\sum_{n=1}^{N}\left(\theta_{o}-\theta_{n}\right)^{2}\right)}{N}}
$$

dimana $N$ adalah banyak data perhitungan, $\theta_{o}$ dan $\theta_{n}$ berturut-turut adalah data MAK dari DoA yang dikehendaki dan data MAK dari DoA yang terukur.

Tabel I

Perbandingan kinerja deteksi amplitudo dari semua estimator dengan RCS bernilai 1.

\begin{tabular}{|c|c|c|c|}
\hline DoA ( $)$ & LS & FCapon & FBCapon \\
\hline-25 & 1,015 & 1,117 & 1,015 \\
\hline-5 & 1,035 & 0,977 & 0,965 \\
\hline 15 & 1,011 & 1,028 & 0,951 \\
\hline
\end{tabular}

Untuk Tabel I maka diperoleh RMSE dari MAK untuk estimator LS, FCapon, dan FBCapon berturut-turut adalah 0,$023 ; 0,071$; dan 0,036. Untuk kondisi kasus sudut $\Theta_{\mathrm{A}}$ ternyata persentase RMSE dari MAK pada estimator FBCapon lebih rendah dibanding FCapon yaitu 3,6\% berbanding $7,1 \%$. Terbukti dari hasil perhitungan RMSE bahwa kinerja estimator FBCapon lebih superior dibanding FCapon. Hal ini juga mendukung hasil studi yang dilaporkan oleh [13] dimana kinerja estimator FBCapon memiliki bias dalam estimasi amplitudo setengah dari yang diperoleh FCapon.

\section{B. Kinerja Estimator terhadap Variasi RCS}

Berdasarkan ulasan pada Bagian IV A tentang kinerja radar PA, untuk kondisi RCS yang bervariasi maka perbandingan kinerja estimator dari metode yang diusulkan terhadap metode yang lain hanya diterapkan 
pada radar MIMO saja. Jika diasumsikan ada tiga target berlokasi di $\Theta_{\mathrm{B}}=\left\{-30^{\circ} ; 0^{\circ} ; 18^{\circ}\right\}$ dengan amplitudo kompleks yang proporsional dengan RCS untuk semua target berturut-turut yaitu $\{1 ; 2 ; 1,5\}$ yang disajikan pada Gambar 2. Pembahasan di bagian ini merupakan kelanjutan dari Bagian IV. A yaitu melihat keunggulan ketiga metode dalam estimasi amplitudo dan DoA.

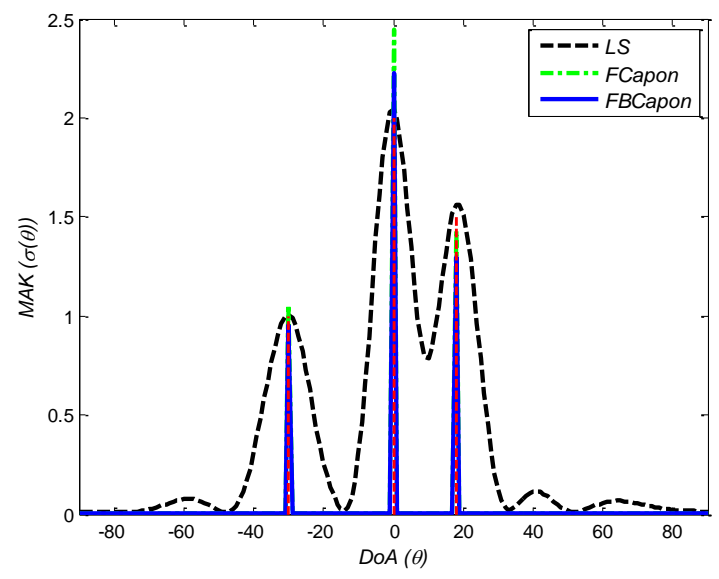

Gambar 2. MAK dari radar MIMO untuk berbagai estimator dengan $\Theta_{\mathrm{B}}$ dan RCS bervariasi.

Tampak dari Gambar 2 bahwa kemampuan deteksi DoA kedua metode Capon lebih akurat dibanding metode LS meskipun ketiga estimator tersebut bisa mendeteksi ketiga target yang diberikan. Tabel II menyajikan data pengukuran dari MAK untuk $\Theta_{\mathrm{B}}$ pada semua estimator untuk radar MIMO. Untuk nilai RMSE dari MAK untuk estimator LS, FCapon, dan FBCapon berturut-turut diperoleh nilai 0,047 ; 0,263 ; dan 0,152 . Untuk kondisi kasus sudut $\Theta_{\mathrm{B}}$ tersebut ternyata persentase $R M S E$ dari MAK pada estimator FBCapon lebih rendah dibanding FCapon yaitu $15,2 \%$ berbanding 26,3\%. Hasil ini juga menunjukkan keunggulan kinerja estimator FBCapon dibanding FCapon yang mendukung hasil studi yang dilaporkan oleh [13].

Tabel II

Perbandingan kinerja deteksi amplitudo dari semua estimator dengan RCS bervariasi.

\begin{tabular}{|c|c|c|c|c|}
\hline $\operatorname{DoA}\left({ }^{\mathbf{0}}\right)$ & RCS & LS & FCapon & FBCapon \\
\hline-30 & 1 & 1,006 & 1,053 & 0,976 \\
\hline 0 & 2 & 2,053 & 2,448 & 2,225 \\
\hline 18 & 1,5 & 1,561 & 1,442 & 1,365 \\
\hline
\end{tabular}

C. Kinerja Estimator terhadap Banyak Sudut Kedatangan Sinyal

Untuk melihat kinerja semua estimator dalam mendeteksi parameter amplitudo maupun DoA maka bisa dilihat dari kemampuannya mendeteksi banyak atau sedikitnya DoA. Pada evaluasi kinerja ini telah dilaksanakan tiga macam eksperimen dimana setiap eksperimen diterapkan dengan DoA yang bervariasi jumlah dan nilainya dimana semua target ber-RCS satu. Tiga macam eksperimen ini bertujuan untuk melihat pengaruh kemampuan estimasi parameter terhadap banyak sedikit DoA.

Pada Gambar 3(a) - 3(b) menunjukkan kinerja dari estimasi parameter untuk ketiga ekperimen khusus pada radar MIMO. Jika diasumsikan ada tiga belas target berlokasi di $\Theta_{\mathrm{C}}=\left\{-60^{\circ} ;-50^{\circ} ;-40^{\circ} ;-30^{\circ} ;-20^{\circ} ;-10^{\circ} ; 0^{\circ}\right.$; $\left.10^{\circ} ; 20^{\circ} ; 30^{\circ} ; 40^{\circ} ; 50^{\circ} ; 60^{\circ}\right\}$ dengan diasumsikan memiliki RCS semua satu yang disajikan pada Gambar 3(a). Terlihat hasilnya bahwa hanya estimator LS yang berfungsi daripada kedua estimator Capon namun dari 13 target yang diberikan tidak semua terdeteksi. Hal ini sesuai dengan studi yang dilaporkan oleh [5] bahwa untuk $K=L=8$ maka jumlah maksimum target yang dideteksi sekitar 7 hingga 32 target.

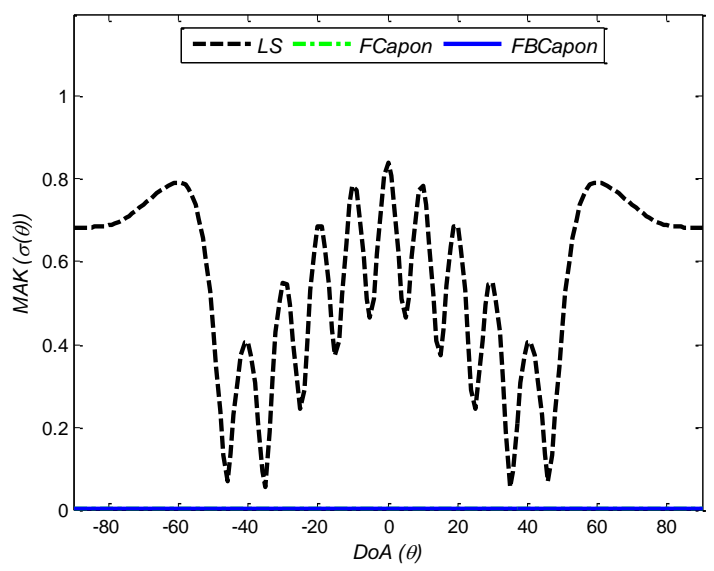

(a)

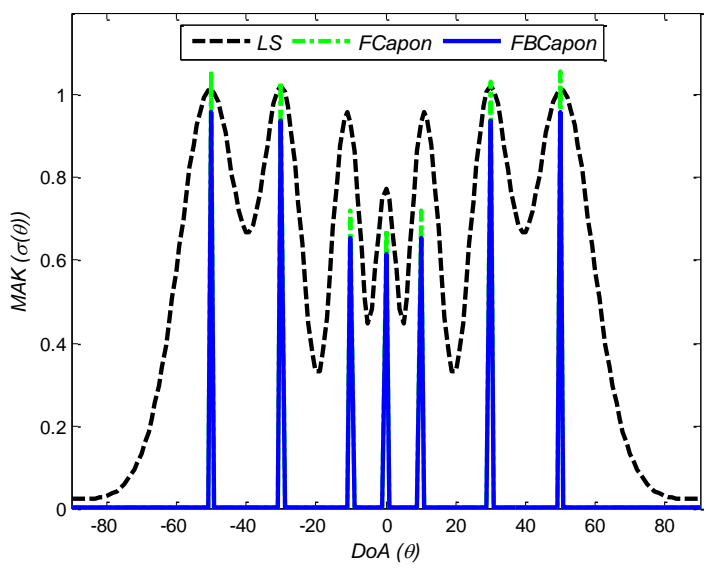

(b)

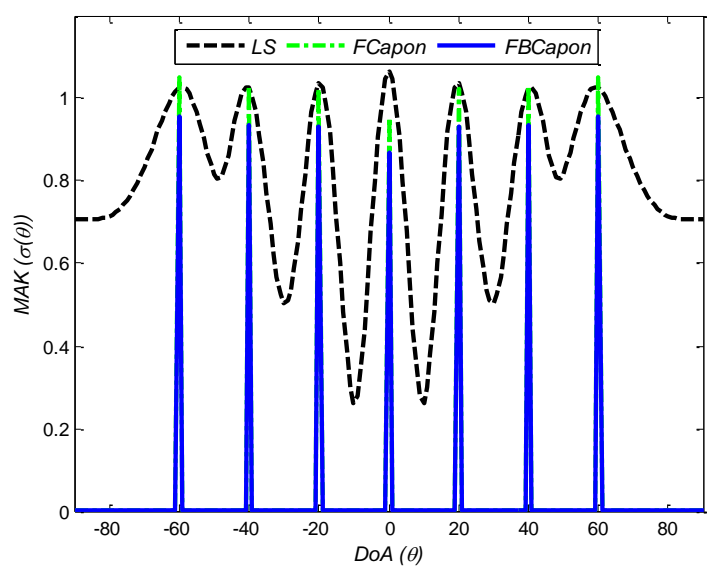

(c)

Gambar 3. MAK pada radar MIMO untuk berbagai estimator yang ber-RCS = 1 dengan DoA yaitu: (a) $\Theta_{\mathrm{C}}$, (b) $\Theta_{\mathrm{D}}$, dan (c) $\Theta_{\mathrm{E}}$. 
Untuk Gambar 3(b) - 3(c), merunjuk pada [5] maka hasil yang diperoleh pada Gambar 3(b) dengan tujuh target berlokasi di $\Theta_{\mathrm{D}}=\left\{-50^{\circ} ;-30^{\circ} ;-10^{\circ} ; 0^{\circ} ; 10^{\circ} ; 30^{\circ}\right.$; $\left.50^{\circ}\right\}$ dan Gambar 3(c) dengan tujuh target yaitu $\Theta_{\mathrm{E}}=\{-$ $\left.60^{\circ} ;-40^{\circ} ;-20^{\circ} ; 0^{\circ} ; 20^{\circ} ; 40^{\circ} ; 60^{\circ}\right\}$ dengan diasumsikan memiliki RCS sama yaitu satu semua mampu dideteksi dengan resolusi yang tepat namun ada beberapa terget yang MAK dari DoA tidak akurat. Seperti pada ulasan di Bagian IV A bahwa semua target mampu dideteksi dengan baik oleh ketiga estimator. Estimasi dari MAK untuk semua DoA mampu dideteksi dengan resolusi amplitudo yang baik oleh estimator LS daripada dengan estimator lain. Namun kondisi sebaliknya bahwa untuk estimasi DoA maka kedua varian estimator Capon memiliki resolusi yang superior dibanding dengan estimator LS.

\section{Resolusi Sudut Antar Dua Target}

Jika diberikan dua DoA yaitu $\theta_{1}$ dan $\theta_{2}$ dan $\delta_{\theta}=\left(\theta_{1}-\right.$ $\theta_{2}$ ), suatu radar memiliki resolusi sudut yang baik jika $\delta \theta$ bernilai sangat kecil dengan nilai minimal $\delta_{\theta}>0$. $\delta_{\theta}$ yang kecil menunjukan seberapa mampu radar untuk membedakan dua lokasi DoA target yang sangat berdekatan. Pada Gambar 4 jika diasumsikan DoA untuk $\theta_{1}=0^{\circ}$ dan $\theta_{2}=5^{\circ}$ maka resolusinya $\delta_{\theta}=5^{\circ}$. Tampak Pada Gambar 4 tersebut bahwa estimator LS tidak mampu mendeteksi kedua DoA tersebut yang berarti resolusi sudut estimatornya rendah. Sebaliknya pada kedua varian estimator Capon mampu mendeteksi kedua target DoA walaupun resolusi amplitudonya tidak mencapai 1 yaitu untuk FCapon dan FBCapon berturut-turut adalah 0,371 dan 0,337. Hal ini sejalan dengan studi yang dilaporkan oleh [7] bahwa estimator Capon memiliki resolusi sudut yang superior dibanding LS.

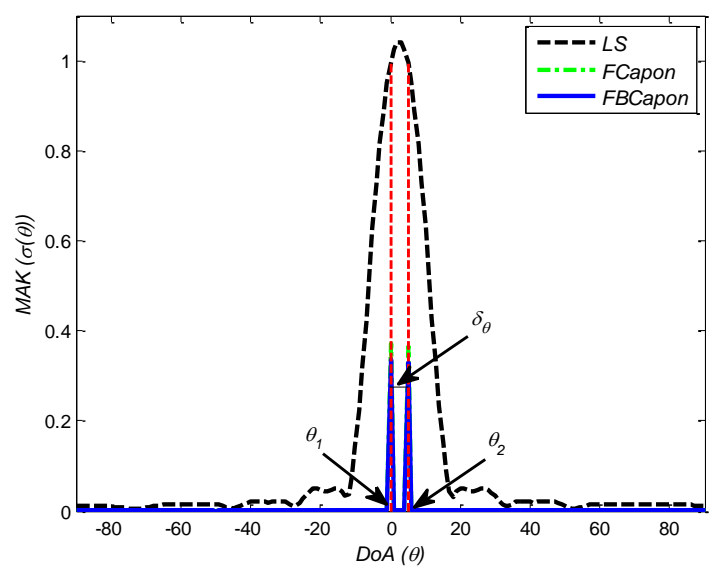

Gambar 4. MAK pada radar MIMO untuk berbagai estimator yang ber-RCS = 1 untuk dengan DoA yaitu: (a) $\Theta_{\mathrm{C}}$, (b) $\Theta_{\mathrm{D}}$, dan (c) $\Theta_{\mathrm{E}}$.

\section{E. Akurasi Deteksi Amplitudo}

Sebagaimana ulasan pada Bagian IV A bahwa kedua estimator Capon unggul dalam hal deteksi DoA dibanding metode LS untuk radar MIMO. Namun memperhitungkan RMSE pada (19) untuk MAK dari ketiga estimator maka bisa dibandingkan kemampuan estimasi amplitudonya terutama varian dari metode Capon. Jika diasumsikan ada lima target berlokasi di $\Theta_{\mathrm{F}}=\left\{-60^{\circ} ;-15^{\circ} ; 0^{\circ} ; 20^{\circ} ; 40^{\circ}\right\}$ dengan amplitudo kompleks yang proporsional dengan RCS untuk semua target berturut-turut yaitu $\{1.5 ; 1 ; 1 ; 2$; $0.5\}$ seperti yang disajikan pada Gambar 5. Untuk nilai RMSE dari MAK untuk estimator LS, FCapon, dan FBCapon berturut-turut diperoleh nilai 0,058; 0,119; dan 0,062. Dari hasil RMSE tersebut untuk kasus sudut $\Theta_{\mathrm{F}}$ ternyata persentase RMSE dari MAK pada estimator FBCapon lebih rendah dibanding FCapon yaitu 6,2\% berbanding $11,9 \%$. Hasil ini juga memperkuat ulasan pada Bagian IV B dimana kinerja estimator FBCapon lebih unggul dibanding FCapon serta juga memperkuat hasil investigasi yang dilaporkan oleh [13].

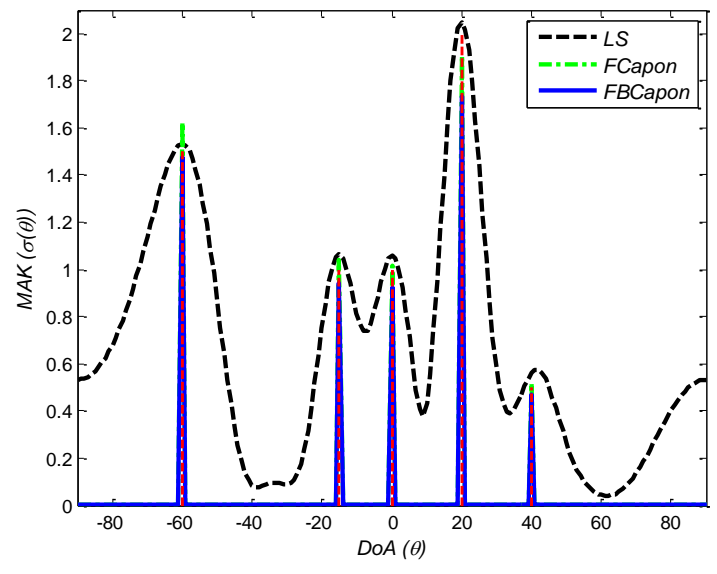

Gambar 5. MAK pada radar MIMO dari berbagai estimator yang bervariasi RCS untuk $\Theta_{\mathrm{F}}$.

\section{F. Jumlah Elemen Antena Tx-Rx}

Untuk mempertimbangkan pengaruh ukuran elemen antena pada kinerja estimator terutama estimator yang diusulkan yaitu FBCapon maka dilakukan pengamatan terhadap berbagai ukuran $K$ dan $L$ pada Tx-Rx radar MIMO. Ukuran $K$ dan $L$ adalah sama dari 2 hingga 12 elemen dengan asumsi Doa dan RCS yang serupa pada pengamatan di Bagian IV E yaitu $\Theta_{\text {F. Tampak pada }}$ Gambar 6 bahwa kemampuan estimator FBCapon untuk mendeteksi DoA dan amplitudo target cenderung tepat bila ukuran $K=L$ naik. Pada kondisi $K=L$ yaitu $2 \leq(K=$ $L)<6$ elemen maka target $\Theta_{\mathrm{F}}$ hanya mampu terdeteksi 2 hingga 3 target. Sementara untuk kondisi $(K=L) \geq 6$ maka target $\Theta_{\mathrm{F}}$ mampu terdeteksi dengan baik oleh estimator FBCapon baik pada jumlah DoA, MAK, dan resolusinya. Hasil dan analisa ini juga menegaskan bahwa memang benar estimator tersebut tidak berfungsi pada radar PA dan seiring bertambahnya jumlah elemen $K$ dan $L$ maka kemampuan estimator juga meningkat seperti yang ditunjukkan pada kinerja radar MIMO.

\section{KESIMPULAN}

Makalah ini telah memformulasi dan mengevaluasi estimasi parameter dari deteksi target dengan metode FBCapon. Kinerja estimasi tersebut telah dibandingkan dengan estimasi konvensional seperti LS dan FCapon dengan mempertimbangkan faktor-faktor seperti jenis radar (PA dan MIMO), variasi RCS, banyak DoA, resolusi sudut antara dua target, akurasi deteksi amplitudo, dan jumlah elemen antena di Tx-Rx. Semua 
estimator, yaitu LS, FCapon, dan FBCapon, bekerja dengan baik jika diterapkan pada radar MIMO namun tidak dengan radar PA karena hanya estimator LS yang berfungsi mendeteksi ketiga target walaupun MAK memiliki resolusi yang tidak tepat.

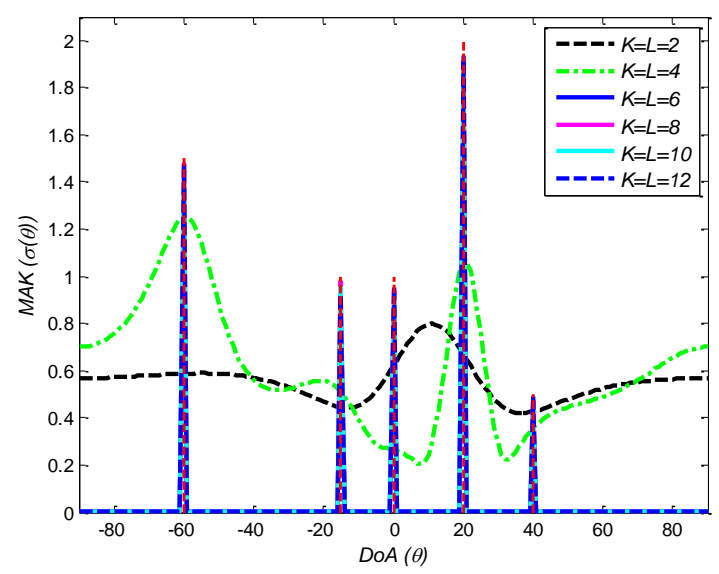

Gambar 6. MAK pada radar MIMO khusus estimator FBCapon dengan $\Theta_{\mathrm{F}}$ dan variasi $K=L$ di Tx-Rx.

Kemampuan deteksi DoA kedua metode Capon lebih akurat dibanding metode LS dimana estimator FBCapon memiliki RMSE separuh lebih rendah dari yang diperoleh FCapon. Jumlah DoA yang mampu dideteksi oleh kedua varian Capon lebih rendah dari ukuran jumlah elemen antena di Tx-Rx yaitu $K$ dan $L$. Resolusi sudut deteksinya lebih baik dari estimator LS, sebagai contoh untuk $K=L$ $=8$ maka diperoleh resolusi sudut $5^{\circ}$ sedangkan estimator LS sebesar $5,8^{\circ}$. Kemampuan estimator FBCapon untuk mendeteksi DoA dan amplitudo target cenderung tepat bila ukuran $K=L$ naik. Untuk pertimbangan aplikasi dan desain sistem radar terutama ketika berhadapan dengan strong interference dan jamming, kedua varian estimator Capon memiliki resolusi sudut DoA dan MAK yang bagus dan tanpa sidelobe sehingga kondisi ini menguntungkan untukpara desainer radar.

\section{REFERENSI}

[1] M. I. Skolnik, Introduction to Radar Systems, 3rd edition, McGraw-Hill, New York, USA, 2001.

[2] J. Li and P. Stoica, MIMO Radar Signal Processing, John Wiley \& Sons, Hoboken, NJ, 2009.

[3] M. Hardiwansyah, S. Tahcfulloh, and G. Hendrantoro, "Parameter Identifiability of Phased-MIMO Radar," in Proc. Int. Conf. Artificial Intelligence and Information Technol., Yogyakarta, Indonesia, Mar. 2019, pp. 192-195.

[4] X. Luzhou, J. Li, and P. Stoica, "Target Detection and Parameter Estimation for MIMO Radar Systems", IEEE Trans. Aerosp. Electron. Syst., vol. 44, no. 3, pp. 927-939, Jul. 2008

[5] S. Tahcfulloh and G. Hendrantoro, "FPMIMO: A General MIMO Structure with Overlapping Subarrays for Various Radar Applications," IEEE Access, vol. 8, pp. 11248 11267, Jan. 2020.

[6] M. R. Widyantara, Sugihartono, F. Y. Suratman, S. Widodo, and P. Daud, "Analysis of Non Linear Frequency Modulation (NLFM) Waveforms for Pulse Compression Radar," Jurnal Elektronika dan Telekomunikasi, vol. 18, no. 1, pp. 27-34, Aug. 2018.
[7] S. Tahcfulloh and M. Hardiwansyah, "Parameter Estimation and Target Detection of Phased-MIMO Radar Using Capon Estimator," Jurnal Elektronika dan Telekomunikasi, vol. 20, no. 2, pp. 60-69, Dec. 2020.

[8] S. Tahcfulloh, and G. Hendrantoro, "Phased MIMO Radar with Coherent Receive Arrays," in Proc. International Conference on Signals and Systems (ICSigSys), Bali, Indonesia, May 2017, pp. 72-76.

[9] C. Gao, H. Zhou, R. Wu, X. Xu, F. Shen, and Z. Guo, "Parameter Estimation and Multi-Pulse Target Detection of Radar MIMO," in Proc. 2016 IEEE Region 10 Conference, Singapore, Nov. 2016, pp. 909-914.

[10] S. Tahcfulloh, "SMIMO Radar: MIMO Radar with Subarray Elements of Phased-Array Antenna," International Journal of Information Technology and Electrical Engineering, vol. 5, no. 2, pp. 37-44, Jun. 2021.

[11] J. Capon (1969), "High Rcsolution FrequencyWavenumber Spectrum Analysis", Proc. IEEE, vol. 57, no. 8, pp. 1408-1418.

[12] P. Stoica, H. Li, and J. Li (1999), "A New Derivation of the APES Filter," IEEE Signal Processing Letters, vol. 6, no. 8, Aug. 1999.

[13] H. Li, J. Li, and P. Stoica, "Performance Analysis of Forward-Backward Matched-Filterbank Spectral Estimators," IEEE Transactions on Signal Processing, vol. 46, no. 7, pp. 1954-1966, Jul. 1998. 